УДК 338.1

\title{
INTEGRATION OF ARTIFICIAL INTELLIGENCE INTO BUSINESS PROCESSES
}

\section{ІНТЕГРАЦІЯ ШТУЧНОГО ІНТЕЛЕКТУ В БІЗНЕС ПРОЦЕСИ}

\section{ИНТЕГРАЦИЯ ИСКУССТВЕННОГО ИНТЕЛЛЕКТА В БИЗНЕС ПРОЦЕССЫ}

\section{Evangelos Siskos}

Ph.D. (Economics), Doctor of Economics, Professor, University of Western Macedonia (Greece, Kozani). Email: siskos@kastoria.teiwm.gr

\section{Konstantia Darvidou}

Ph.D. (Economics), University of Western Macedonia (Greece, Kozani)

\section{Lytvynenko N.P.}

$\mathrm{PhD}$ in Economics, Associate Professor, Institute of International Relations of Taras Shevchenko National University of Kyiv( Kyiv, Ukraine)

\section{Khmara M.P.}

$\mathrm{PhD}$ in Economics, Associate Professor, Institute of International Relations of Taras Shevchenko National University of Kyiv(Kyiv, Ukraine) E-mail: marynahmara@gmail.com

\section{Свангелос Сіскос}

Доктор економічних наук, професор, Університет Західної Македонії (Козані,Греція) Еmail: siskos@kastoria.teiwm.gr

\section{Константіа Дарвідоу}

Кандидат економічних наук, професор, Університет Західної Македонії (Козані,Греція) E-mail

\section{Литвиненко Н.П.}

Кандидат економічних наук, доцент, Інститут міжнародних відносин Київського національного університету імені Тараса Шевченка (Київ, Україна)

\section{Хмара М. П.}

Кандидат економічних наук, доцент, Інститут міжнародних відносин Київського національного університету імені Тараса Шевченка (Київ, Україна) E-mail: marynahmara@gmail.com

Abstract. AI performs many tasks, including - creating and working in symbolic computing systems, creating and working in systems with fuzzy logic, cognitive psychology, understanding natural language, creating expert systems, computer linguistics, automation of various vocabulary and lexical cards, behavior planning (search and proposal of the most optimal way to achieve the goal, based on this situation), machine translation, creation and management of intelligent robots and groups of mobile robots, etc.

Key words: AI, Business processes, Business Process Management (BPM)

Аннотація. ШІ виконує безліч завдань, серед яких - створення і робота в системах символьних обчислень, створення $і$ робота в системах з нечіткою логікою, когнітивна психологія, розуміння природної мови, створення експертних систем, комп'ютерна лінгвістика, автоматизація процесів ведення різних словникових та лексичних карток, 
планування поведінки (пошук і пропозиція найбільш оптимального шляху для досягнення поставленої мети, виходячи з даної ситуації), машинний переклад, створення і управління інтелектуальними роботами і групами мобільних роботів тощяо.

Ключові слова: ШІ (штучний інтелект), бізнес процеси, менеджмент бізнес проиесів (МБП)

Аннотация. ИИ выполняет множество задач, среди которых - создание и работа в системах символьных вычислений, создание и работа в системах с нечеткой логикой, когнитивная психология, понимание естественного языка, создание экспертных систем, компьютерная лингвистика, автоматизация процессов ведения различных словарных $u$ лексических карточек, планирования поведения (поиск $u$ предложение наиболее оптимального пути для достижения поставленной иели, исходя из данной ситуации), машинный перевод, создание и управление интеллектуальными работами и группами мобильных роботов и тому подобное

Ключевые слова: ИИ (искусственный интеллект), бизнес процессы, менеджмент бизнес прочессов (МБП)

Introduction. One of the key features of the 21 st century world economy development is the transition from the traditional vertical form of organization management to the concept of Business Process Management (BPM), which considers business processes as the main resources of the enterprise, the effective use of which leads to increased productivity.

Today, in addition to the constant factors of successful business process management, such as building a process architecture, defining key business processes and Key Performance Indicators (KPIs) and the distribution of areas of responsibility, the degree of process automation is one of the key factors. Along with the rapid development of information technology, and especially artificial intelligence (hereinafter referred to as "AI"), process owners are increasingly aimed at:

- minimization of the involvement of human resources in the functioning of the business process;

- automation of the relevant business process scenarios, which should be launched after the occurrence of certain events, taking into account the state of internal and external systems, people, different types of restrictions, etc.;

- reengineering business processes through the use of advanced technologies.

Main research results. Mass application of AI technologies in the activities of organizations can lead to a number of serious consequences in the world: a sharp increase in labor productivity, improving the efficiency of the economy, changing the structure of the labor market, a radical rethinking of common norms and more.

New needs of organizations and the rapid development of information technology, including AI, the consequences of which can change the basic subsystems of the world economy and lead to a rethinking of sustainable social norms, are the reasons for choosing this topic in writing a term paper.

As Daniel Hulme, a leading expert in AI and new technologies, noted: "Artificial Intelligence is everywhere. AI isn't just a new set of tools. It's the new world. From automation to augmentation and beyond, AI is already starting to change everything" [21].

The term "artificial intelligence" appeared in 1956, but the real popularity of AI technology has reached only today against the background of increasing data volumes, improving algorithms, optimizing computing power and storage. In the 1980s, scientists Barr and Feigenbaum proposed a definition of artificial intelligence. Artificial intelligence is a field of computer science that develops intelligent computer systems. These systems are grouped into a separate category because they may have abilities that are related to the abilities of the human mind - speech and foreign language recognition, learning and reasoning, and so on. Currently, AI includes appropriate software systems and algorithms that can solve any problem just like the human mind. 
According to Daniel Hulme, there are two definitions of AI, the first definition refers to machines that can perform tasks that have traditionally been in the realm of human beings. Humans are the most intelligent beings we know, so when we begin to see machines perform tasks once available only to humans, then we assume that they are intelligence.

The second definition of intelligence - artificial or human - is adapted, goal-oriented behavior. The word goal is used here in the sense of trying to achieve a goal, which in business may be to work more effectively with staff or allocate marketing costs. Behavior is how quickly or without friction you can move resources to achieve a goal. But the key word in defining target adaptive behavior is adaptive. If your computer system does not make a decision and then finds out if it was a good or a bad decision, and adapts its own internal model of the world, it's not AI technology. Therefore, the real definition of AI is a system that can learn and adapt without human help. Adaptability is synonymous with intelligence [21].

Due to the fact that the evolution of the term and definition of AI is constantly continuing, I think it is appropriate to mention the effect of AI. The effect of AI is understood as a state in which experts and specialists devalue the value of AI skills every time a new level of result is achieved, which was unattainable within the previous paradigm.

AI also includes software systems such as heuristics, namely those designed to work in accordance with algorithms for which there is currently no or no defined formal solution model, i.e. they are based on experience in decision making. This is very similar to the human decision-making process in difficult situations. Heuristic software systems as a method of solving particularly difficult organizational issues in an uncertain information situation is still in the process of formation, but the interest in it of scientists and organizers of production management is constantly growing.

AI task - a list of tasks in which the process of finding a solution is formalized. The following systems are most widely used to solve the following problems:

- pattern recognition;

- modeling of considerations;

- creation and work in systems of symbolic calculations;

- creation and work in systems with fuzzy logic;

- cognitive psychology;

- understanding of natural language;

- creation of expert systems;

- computational linguistics;

- automation of processes of maintaining various vocabulary and lexical cards;

- behavior planning (search and proposal of the most optimal way to achieve the goal, based on this situation);

- machine translation;

- creation and management of intelligent robots and groups of mobile robots [8].

Solving problems with the help of AI - setting, analysis and presentation of specific situations, in the development and implementation of solutions which require ingenuity, the ability to learn, generalize, draw conclusions. Computer technology is usually used to implement extremely complex intellectual processes for finding solutions, in cases where the final result is unpredictable or is the end of a series of logical conclusions.

Machine intelligence and machine learning are used for all these purposes.

Machine intelligence is a set of computer hardware and software, which provides such human-machine communication (interface), which in its level is close to the communication between specialists who solve a common problem.

Machine learning is a set of such methods and technologies of AI, which are characterized not by problem solving, but by learning to apply solutions to certain similar problems.

The classification system of AI is a long-standing issue in the study of AI technology. Consider the classical classification that divides AI into: 
- automated (to perform routine tasks);

- auxiliary (optimizes human decisions);

- extended (aimed at supporting human thinking in extreme situations);

- autonomous (carries out independent activities similar to human thinking).

According to the type of perception of the environment, the AI system can be divided into:

- those who react (only analyze the environment and form a corresponding reaction);

- with limited memory (adjusts its behavior based on previous "experience", such as unmanned vehicles);

- with elements of the mind (able to recognize thoughts and emotions);

- $\quad$ "Strong AI" (which can be compared in mental abilities with a person).

- Another classification is also adopted, which distinguishes among AI systems:

- those with intelligent interfaces and feedback;

- those that are automated to recognize objects;

- neural networks;

- expert systems;

- automated control systems (ACS) for decision support;

- cognitive modeling;

- establishment of empirical data and their intellectual analysis.

There is a classification for the acquisition of the ability to think and become self-aware: strong and weak AI.

It should be noted that each researching $\mathrm{AI}$ author proceeds from the applied nature of $\mathrm{AI}$ in any science. Consider the approaches used.

Symbolic approach (allows you to operate with weakly formalized ideas and their meanings). A key feature of symbolic calculations is the creation of new rules in the process of program execution.

Logical approach (based on modeling of reasoning and logic). The logical approach can be illustrated by the use of a logical programming language and system for these purposes.

Agent-oriented approach (based on the use of intelligent agents. Intelligence is seen as a computing part of the machine and the ability to achieve its goals. Such a machine is an intelligent agent that measures and analyzes the environment with sensors. In addition, it has the ability to influence objects by means of executive mechanisms.

This approach focuses on those methods and algorithms that will help the intelligent agent to survive in the environment while performing its tasks. In such approaches, algorithms for finding a way and making decisions are studied much more carefully.

Hybrid approach (involves a synergistic combination of neural and symbolic models).

Intelligent information system (IIS) is based on the concept of application of databases and accumulated knowledge in order to create algorithms for solving various applications depending on specific needs.

IIS is characterized by:

- communication skills;

- ability to find solutions to poorly formalized problems, as well as to self-study based on the results of the decision;

- adaptability.

The principle of AI's functioning is to combine a large amount of data with the ability to fast, interactive processing and intelligent algorithms, which allows programs to automatically learn based on the patterns and features contained in the data. AI is a complex discipline with many theories, techniques and technologies. Its main directions are as follows.

Machine learning is a field of knowledge that explores algorithms that are learned from data in order to find patterns. It uses methods of neural networks, statistics, operations research, etc. to reveal hidden useful information in the data; this clearly does not program instructions that indicate where to look for data and how to draw conclusions. 
Neural network is one of the methods of machine learning. This is a mathematical model, as well as its software or hardware implementation, built on the principle of organization and functioning of biological neural networks - networks of nerve cells of a living organism.

In-depth learning uses complex neural networks with many neurons and layers. Increased computing power and improved techniques are used to train these deep neural networks, as well as to identify complex patterns in vast arrays of data. Common applications: image and speech recognition.

Cognitive computing is the direction of AI, the task of which is to ensure the process of natural human interaction with the computer, similar to the interaction between people. The ultimate goal of AI and cognitive computing is the simulation of human cognitive processes by a computer through the interpretation of images and speech to obtain an appropriate response.

Computer vision relies on pattern recognition and in-depth learning to recognize images and videos. Machines already know how to process, analyze and understand images, as well as take photos or videos and interpret the environment.

Natural language processing is the ability of computers to analyze, understand and synthesize human language, including oral speech. We can now control computers using ordinary language used in everyday life. For example, using Siri or Google assistant.

In addition, the operation of $\mathrm{AI}$ is provided by other important technologies.

The existence of AI is impossible without graphics processing units (GPUs), as they provide the computing power needed for iterative data processing. "Big data" and computing resources are needed to train neural networks.

The Internet of Things collects huge amounts of data from connected devices. Most of this data has not been analyzed. Automating models with AI will allow you to use more of this data.

More sophisticated algorithms are being developed and combined in a new way, which allow faster analysis of a larger amount of data at several levels. Such intelligent processing is the key to detecting and predicting rare events, understanding complex systems and optimizing unique scenarios.

Application programming interfaces (APIs) are mobile code packages through which AI functionality can be integrated into existing products and software packages. With the API, you can add an image recognition feature to your home security system or question-and-answer functions to describe data, create captions and headings, and identify interesting patterns in your data and other useful information.

Speaking about AI technologies in business, let us remember the words of Daniel Hulme: "If used correctly, this can absolutely change your business. But there's a lot of hype out there, and a lot of people investing in these technologies don't know what they're doing" [21].

Among all AI technologies, there are five that can change business processes in the foreseeable future most profoundly and CIOs are advised to closely monitor their development.

Augmented intelligence.

To augmented intelligence systems, analysts include automation tools that help increase the productivity of mental work. They help to organize a "partnership" between people and $\mathrm{AI}$, in which the former play the leading role.

The use of artificial intelligence in this capacity helps to reduce the amount of routine work and, accordingly, the number of errors during its execution. And human participation, in turn, will reduce the risk associated with automated decision-making - due to the fact that people will be able to solve questions to which AI has not yet been trained [20].

Chatbots.

Chatbots, the "face" of artificial intelligence that we encounter almost every day, are also changing the way we interact with customers. For example, at Kia, they help 115,000 car owners solve their problems every week, and at the German network of discounters Lidl, a bot named Margot gives customers advice on choosing wines and snacks.

Chatbots can be text and voice, they answer standard questions according to a script compiled in advance based on the experience gained by live operators. They can be used to solve 
the tasks of human resources or technical support, to help employees adapt to a new location, etc. But to the greatest extent, these AI solutions have changed the customer service process. If before the user usually had to study the interface with the system, now the chatbot "studies" the user, "guessing" his intentions and prompting further action [20].

Machine learning.

Among the tasks that can be solved by machine learning - personalization of customer service, dynamic pricing, disease diagnosis, combating money laundering and much more. The principle of operation of machine learning tools is identification of patterns present in the data using mathematical models. Machine learning is increasingly used, which is facilitated by the rapid growth of data in organizations and the active development of computing infrastructures.

Machine learning helps to optimize processes and find new solutions to business problems in a variety of industries. For example, in American Express, machine learning algorithms and analysts recognize fraud attempts in near real time, saving the company millions by preventing losses. And at Volvo, analytical systems predict probable failures and the need for repair and maintenance of various components of cars, helping to increase their safety [20].

AI control system.

Experts are convinced that the creation of an AI governance system at enterprises cannot be neglected. This is necessary, inter alia, to understand and control the potential risks associated with the regulation and the possibility of damage to reputation. The AI management system is based on specially designed policies to prevent AI system errors ("bias"), discrimination of users or groups of users on certain grounds and other possible negative consequences of the use of artificial intelligence.

When developing the AI management system, experts recommend that analysts and CIOs pay attention to three areas: trust, transparency and the principles of ethnocultural diversity. The need to be able to trust data sources and the results of AI systems is one of the cornerstones of their successful implementation, and the development of transparency requirements for data sources and algorithms will reduce risks. Concern for compliance with the principles of diversity in data and algorithms contributes to the ethics and accuracy of the results of AI-based solutions [20].

Smart apps.

For several years, the only opportunity to implement artificial intelligence was the independent development of AI systems. However, today most organizations prefer not to develop such solutions and not even buy individual AI systems, but to obtain AI tools as part of corporate applications.

Initially, analytics tools with built-in AI technologies were the most "intelligent". Recently, however, suppliers of a variety of enterprise applications - ERP, CRM, human resource management and office suites are embedding AI tools in them and are beginning to create AI platforms [20].

How to integrate AI technology into business processes?

Find possible ways to implement AI technologies with the highest return on investment. Test the previous concepts carefully in order to make a decision as soon as possible. Find innovative solutions on a large scale.

Future AI leaders are defining their strategies today. Organizations can start with lowrisk/high-impact pilot programs, but for long-term success they need to:

- to coordinate the AI strategy with the business strategy;

- to develop the possibility of adopting AI at the enterprise level;

- to create institutionalized models of work with AI capabilities;

- create an appropriate AI department to ensure safety and reduce risks [1].

- Problems in which AI and machine learning could help:

1. AI will change the landscape of the labor industry. One of the right ways for AI is to transform the business through automation. Large-scale manufacturing companies will use AI to replace human labor because it is cheaper, more accurate, more productive, and less prone to error. Other business sectors that are heavily modified due to the implementation of AI are administrative 
functions such as administrators and assistants, as well as customer service. Responding to calls for day-to-day accounting, AI platforms will handle the same much better, saving a lot of money for companies and increasing efficiency.

2. Increasing the mobility of enterprises. Enterprise mobility is the future of foreign-invested business, as the working model of the central office gradually shifts to the model of working from home or other remote locations. With the development of AI solutions, employers will be able to give employees the opportunity to work anywhere. Excellent enterprise mobility will allow employees to control their schedules and environment, paving the way for increased efficiency and productivity. AI will also allow such employees to acquire new skills and improve their portfolio to become more competent in a much easier way, as they do not need to be physically present in training and other training programs.

3. Increased efficiency and higher accuracy at lower costs. With the advent of AI, the minimum error and errors that cause additional costs to businesses, as well as loss of productivity, will be minimized. Businesses will be able to enjoy greater efficiency and accuracy because AI eliminates human error and creates fewer risks for business. In addition, machines run faster than humans and do not have to pay, so it will also be cost-effective and save a lot of money for the business. Moreover, thanks to its strong and fast computing capabilities, AI programs could process large data sets much faster, helping businesses reach high levels in strategy development, forecasting and business growth planning.

4. AI will help integrate and consolidate business operations. In line with new business development trends for business in 2020, AI will also help businesses consolidate and integrate their business processes. One of the main problems facing large enterprises is the fragmentation of various business processes and the creation of poor synergies. AI technology, integrated into enterprise resource planning (ERP) solutions, will be able to use fragmented work pieces and integrate them into a complete whole, testing and analyzing each information. This will consolidate employees, operations and systems and, as a result, increase efficiency, productivity and revenue.

5. AI will pave the way for stronger protection against cyberattacks and fraud. With the development of stronger AI, cybersecurity programs will be better equipped to test and predict cyberattack scenarios and find security gaps. Improving neural networks help analyze user behavior and detect suspicious transactions, as well as create algorithms to prevent financial losses. AI has great potential with its ability to study models of networks, devices and systems, as well as to decode deviations that can detect attacks in the process.

6. AI will help keep the equipment in good condition longer. For example, AI can predict equipment failure, which saves money on ongoing scheduled inspections. You can also use it to replace equipment parts just when you need them, not when "recommended by the manufacturer". And having carefully studied and tested the digital model of your equipment, you can optimize its performance online depending on various factors.

7. Development of marketing strategy on the basis of the provided data and the set purposes. Artificial intelligence helps in the work of a marketer: not only analyzes the experience of previous sales, but also uses forecasting to "predict the future", as well as takes into account the behavior of competitors and the general market situation.

Currently, AI performs many tasks, including - creating and working in systems of symbolic calculations, creating and working in systems with fuzzy logic, cognitive psychology, understanding natural language, creating expert systems, computer linguistics, automation of various vocabulary and lexical cards, behavior planning (search and proposal of the most optimal way to achieve the goal, based on this situation), machine translation, creation and management of intelligent robots and groups of mobile robots, etc.

The introduction of AI requires a significant change in business processes, and new solutions that use AI technology can lead to the creation of new business processes that open up new business opportunities: the influx of customers, increased profits, increased loyalty, etc. 


\section{References}

1. Artificial Intelligence everywhere [Електронний ресурс] - Режим доступу до pecypcy: https://www.pwc.com/gx/en/issues/data-and-analytics/artificial-intelligence.html.

2. Brynjolfsson, Erik and Tom Mitchell. (2017) "What Can Machine Learning Do? Workforce Implications." Science 358(6370): 1530-1534.

3. Didur I. Dynamic pricing algorithms on Uber and Lyft [Електронний ресурс] / Ivan Didur - Режим доступу до ресурсу: https://datarootlabs.com/blog/uber-lift-gett-surge-pricingalgorithms.

4. Estonia accelerates artificial intelligence development [Електронний ресурс] Режим доступу до ресурсу: https://e-estonia.com/estonia-accelerates-artificial-intelligence/.

5. Ethical AI: Tensions and trade-offs [Електронний ресурс] - Режим доступу до pecypcy: https://www.digitalpulse.pwc.com.au/ethical-artificial-intelligence-tensions-trade-offs/.

6. G20 Ministerial Statement on Trade and Digital Economy [Електронний ресурс] Режим доступу до ресурсу: https://www.mofa.go.jp/files/000486596.pdf.

7. Hovy E. Collaboratively built semi-structured content and Artificial Intelligence: The story so far [Електронний ресурс] / E. Hovy, R. Navigli, S. Ponzetto - Режим доступу до pecypcy: https://www.sciencedirect.com/science/article/pii/S0004370212001245 $484 \mathrm{c}$.

8. John Wiley \& Sons. An Introduction to MultiAgent Systems / John Wiley \& Sons. -

9. Johnson K. CB Insights: AI startup funding hit new high of \$26.6 billion in 2019 [Електронний pecypc] / Khari Johnson - Режим доступу до ресурсу: https://venturebeat.com/2020/01/22/cb-insights-ai-startup-funding-hit-new-high-of-26-6-billion-in$2019 /$.

10. Kai-Fu Lee. AI Superpowers: China, Silicon Valley, and the New World Order / Kai-Fu Lee., 2018. - 275 c.

11. Parmy O. Nearly Half Of All ‘AI Startups’ Are Cashing In On Нуре [Електронний pecypc] / Olson Parmy - Режим доступу до ресурсу: https://www.forbes.com/sites/parmyolson/2019/03/04/nearly-half-of-all-ai-startups-are-cashing-inon-hype/\#32e78d08d022.

12. Psychometric theories [Електронний pecypc] - Режим доступу до ресурсу: https://www.britannica.com/science/human-intelligence-psychology/Psychometric-theories.

13. Recommendation of the Council on Artificial Intelligence [Електронний ресурс] Режим доступу до ресурсу: https://legalinstruments.oecd.org/en/instruments/OECD-LEGAL0449.

14. Revenues from the artificial intelligence (AI) software market worldwide from 2018 to 2025 [Електронний ресурс] - Режим доступу до ресурсу: https://www.statista.com/statistics/607716/worldwide-artificial-intelligence-market-revenues/.

15. Saran C. Stanford University finds that AI is outpacing Moore's Law [Електронний pecypc] I Cliff Saran - Режим доступу до ресурсу: https://www.computerweekly.com/news/252475371/Stanford-University-finds-that-AI-isoutpacing-Moores-Law.

16. Sebastian A. DeepMind in talks with National Grid to reduce UK energy use by $10 \%$ [Електронний pecypc] / Anthony Sebastian - Режим доступу до ресурсу: https://arstechnica.com/information-technology/2017/03/deepmind-national-grid-machine-learning/.

17. Swpending in Artificial Intelligence to Accelerate Across the Public Sector Due to Automation and Social Distancing Compliance Needs in Response to COVID-19, says IDC [Електроннй ресурс] - Режим доступу до ресурсу: https://www.idc.com/getdoc.jsp?containerId=prEUR146205720.

18. The History of Artificial Intelligence [Електронний ресурс] / C.Smith, B. McGuire, T. Huang, G. Yang - Режим доступу до ресурсу: https://courses.cs.washington.edu/courses/csep590/06au/projects/history-ai.pdf. 
19. Three governance considerations to unlock the potential of AI [Електронний pecypc] - Режим доступу до ресурсу: https:/www.digitalpulse.pwc.com.au/ai-governanceconsiderations/.

20. Top Trends on the Gartner Hype Cycle for Artificial Intelligence, 2019 [Електроннй ресурс] - Режим доступу до ресурсу: https://www.gartner.com/smarterwithgartner/top-trends-on-the-gartner-hype-cycle-for-artificialintelligence-2019/.

21. Understanding the Potential of Artificial Intelligence [Електронний ресурс] Режим доступу до ресурсу: https://www.strategy-business.com/article/Understanding-thePotential-of-Artificial-Intelligence?gko=c3fb6.

22. What is the impact of AI on government policy and society? [Електронний ресурс] - Режим доступу до ресурсу: https://www.pwc.com/gx/en/issues/data-and-analytics/artificialintelligence/government-reaction.html.

23. Wiggers K. AI Weekly: Amazon plays the long game in health care AI [Електронний pecypc] / Kyle Wiggers - Режим доступу до ресурсу: https://venturebeat.com/2019/12/06/ai-weekly-amazon-plays-the-long-game-in-health-care-ai/.

24. Wiggers K. Amazon's AutoGluon produces AI models with as little as 3 lines of code [Електронний pecypc] / Kyle Wiggers - Режим доступу до ресурсу: https://venturebeat.com/2020/01/09/amazons-autogluon-produces-ai-models-with-as-little-as-threelines-of-code/. 